\title{
Dnaj Homolog Subfamily B Member 6
}

National Cancer Institute

\section{Source}

National Cancer Institute. Dnal Homolog Subfamily B Member 6. NCI Thesaurus. Code C102932.

Dnaj homolog subfamily B member 6 (326 aa, $\sim 36 \mathrm{kDa}$ ) is encoded by the human DNAJB6 gene. This protein is involved in the mediation of protein folding and the inhibition of protein aggregation. 